UDC $669.187 .046 .582: 621.365 .3$

\title{
エレクトロスラグ溶解条件に及ぼす 溶解バラメータの影響*
}

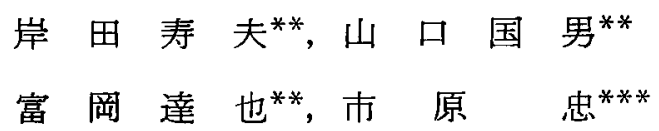

Effect of Melting Parameter in the Electroslag Remelting Process

\author{
Toshio Kishida, Kunio Yamaguchi, \\ Tatsuya Tomioka and Tadashi Ichihara
}

\section{Synopsis}

On the ESR operation results obtained for the past 3 years, in the ESR using a mold of $230 \sim 560 \mathrm{~mm}$ dia. voltage, current, kind of slag, slag amount, electrode mold dia. ratio (d/D) and we analyzed the influences of these parameters on the optimum melting condition on the base of operation data and measuring results of depth and shape of molten metal pool by FeS addition.

In the ESR it is important to select proper melting parameters for obtaining the highest quality. And it is advisable to control the melting speed optionally from the point of balance with solidification.

\section{1. まえがき}

エレクトロスラグ再溶解法 (ESR) の技術が開発 され，実用化されて約10年を経過し，日本における月 間溶解量も2 3千 $\mathrm{t}$ K達するに至った。この間技術 面での進歩は著しく，理論的な裹付けす徐々に行われ 溶解法として一つの技術か確立しつつある。

ESRのおすな特改である高蕰スラグ中での精錬反 応，薄いスラグ層を通しての伝熱による独特の凝固機 構, 入力パターンによる任意の溶解制御など，これら

昭和49年 8 月 7 日受付

*第 4 回 ESR 国際シンポジウム（1973）東京扰よ び学振19委（1973）11月に一部発表

**大同制銅姝涉川工場

***大同製鎆柏高葴製作所
の技術を最適に組合わせて最高の品質を得るためには まだ末解決な面も残されており，とくに大型鎆塊にお いては凝固を中心として検討を要する課題が多い。 ESR は再溶解法として類似の真空アーク再溶解法 （VAR）とよく品質，溶解技術を比較して論じられ るが, VARより条件, 要素が多〈複雑であり1), 溶 解上のノゥ・八ウが重要である。

溶解条件選定のための溶解パラメータについては

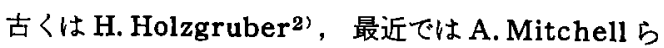
8 B)による報告がある。また，スラグに関してる数多 くの報告7 9) があるが，実際操業之品質とを対比させ た報告は各社のノウ・八ウに属するため少ない。今回 は ESRの一連の報告の一つとして，溶解条件を決定 するバラメータについて，径 230〜 560 mm 鋼塊での溶 解経験を基にして述べる。

溶解パラメーターのおるなるのとして, 
1）精錬および溶解を支配するスラグ条件。

2 ）溶解速度を支配する入力条件およぴ電極条件。

3）凝圆条件を支配する鋳型条件および冷却条件。 などに分けられるが，これらの条件はさらに細分さ れ，相互に関保かからみ合 5。

ESR では要求される品質によりスラグ条件を選定 し,さらに溶解パターンを決定して溶解速度を制御す る方法が一般に採用されるが，鋼種によっては逆に溶 解速度を最初に決め, その後スラグ, 溶解条件を選定 する場合もある。

\section{2. 溶解パラメータの溶解に及ぼす影箁について}

溶解パラメータの選定により，銅塊のはた，内質な どに影響のあることは衆知の事実である。その 1 例と して溶解時に等速溶解を採用した場合, 電極鋳型径比 (d/D)，および入力の減少により鋳はだおよび内質 が不良となった例を Fig. 1 に示す。等速溶解を採用

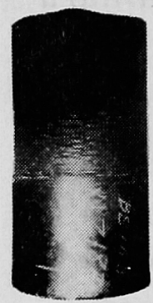

\begin{tabular}{|l|c|l|l|}
\hline Power & Melting rate & $\begin{array}{c}\text { Power } \\
\text { consumption }\end{array}$ & $\mathrm{d} / \mathrm{D}$ \\
\hline 290 & $280^{\mathrm{kg} / h r}$ & 1,040 kth/t & 0.69 \\
\hline 290 & 240 & 1,200 & 0.667 \\
\hline 300 & 250 & 1,200 & 0.663 \\
\hline 330 & 240 & 1,480 & 0.65 \\
\hline 370 & 24.0 & 1,540 & 0.637 \\
\hline 460 & 265 & 1,740 & 0.623 \\
\hline 570 & 255 & 2,130 & 0.61 \\
\hline
\end{tabular}

Fig. 1. Melting condition of inferior surface ESR ingot.

した場合溶解の後半入力が隇少しd/D比の增大と合わ せてスラグ温度の低下を招き “Ripples” 欠陥を生じ た例である。この例でわかるよ5に，ESRには適切 な溶解バラメータの選定がより良い品質を得るために 重要である。

\section{1 電圧の影隌}

ESR の溶解条件を決める 要因として電圧の影響が ある。ESRにおける電圧はスラグの抵抗, 溶解法, $\mathrm{d} / \mathrm{D}$ などにより決まるが，普通40〜60Vの間にある。 したがって，入力としての変化量は $50 \% に$ 過きない が，溶解速度および品質には大きな影響を与える。

\section{1. 1 電極漫せき深さと電圧との関係}

ESRにおける電圧が単純に電極とメタルプールの 極間距離により決むるとすると電圧の決定要素は浸せ き深さであるが，実際にはスラグ盜度，電流の流れ 方，フーク発生の有無，電栖先端での界面条件により かなり異なった様相を示す。これらについてはモデル 実験での報告11'も多い。

Fig. 2 は電極浸せき深さと電圧の関保を示した図 であるか界面近くになり，微少アーク発生域となると

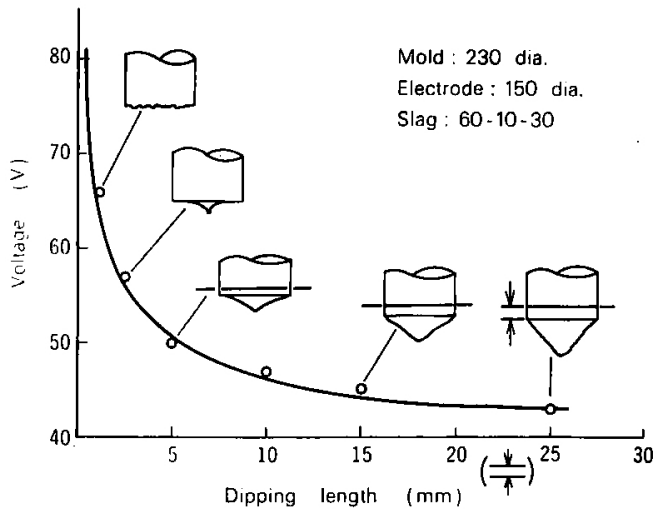

Fig. 2. Relationship between electrode immersion depth and voltage.

電圧の上昇が著しく，界面近く，すなわち高電圧での 操業は優秀な制御装置を必要とする。また，漫せき状 態での電力と同程度の電力で電圧を界面アーク状態に 保った場合は溶解速度は約 2 倍に達することがあり， 低電力で溶解速度を上げるには電圧を高く取ることが 好ましい。Fig. 3 は浸せき状態および界面アーク発

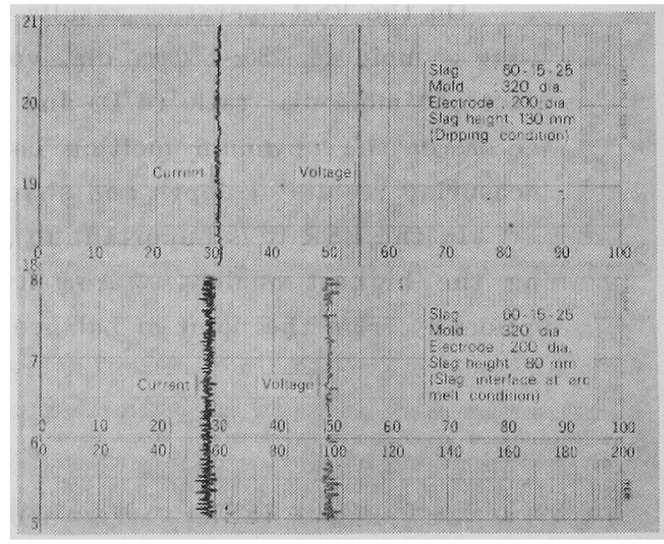

Fig. 3. Electric current and voltage at the time of ESR.

生域での電压の記録誌の例であるが，浸せき状態では 電圧の変動がなく一定であり，一方界面状態では定速 で下降させても電圧の変動は大きく，変動幅が $5 \mathrm{VK}$ も達することがある゙。

\section{1. 2 スラグ条件による電圧の推移}

スラグの条件としては，スラグの種類とスラグの量 （スラグ浴の高さ）とスラグ組成の溶解中の変化があ る。スラグの固有抵抗は $0.6 \Omega \cdot \mathrm{cm}$ から $0.2 \Omega \cdot \mathrm{cm}$ 程 度の值であり，スラグの組成すなわち $\mathrm{Al}_{2} \mathrm{O}_{8}$ 拉よび $\mathrm{CaO}, \mathrm{SiO}_{2}$ の量によって決まる。 $\mathrm{Al}_{2} \mathrm{O}_{3} ， \mathrm{CaO}$ は抵 


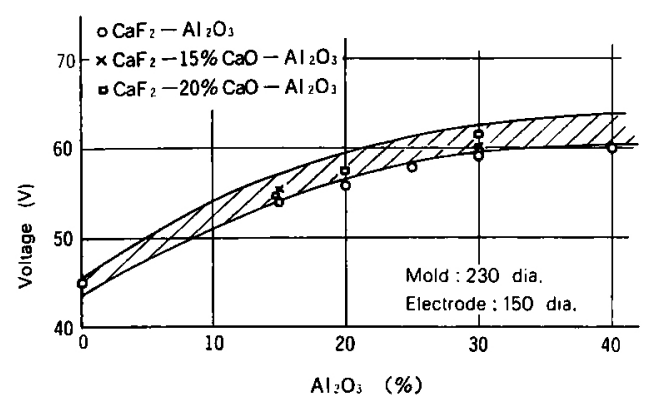

Fig. 4. Relationship between $\mathrm{Al}_{2} \mathrm{O}_{3}$ amount and voltage.

抗值の増大， $\mathrm{SiO}_{2}$ は抵抗值を减少させることが知ら れている。界面アーク状態に近い状態での $\mathrm{Al}_{2} \mathrm{O}_{3}$ の量 による溶解電圧の変化を Fig. 4 に示す。図でもわか るように界面アーク状態では $\mathrm{Al}_{2} \mathrm{O}_{3}$ の量による変化は それほど大きくない。しかし，浸せき状態ではスラグ 組成によってかなり変動する。夹際には $\mathrm{CaF}_{2}-\mathrm{Al}_{2} \mathrm{O}_{3}$ の 2 元系では溶解中に $\mathrm{CaF}_{2}$ の分解による $\mathrm{CaO}$ ，また， 3 元系ではCaOの量により抵抗值が異なり, 同じ $30 \%$ $\mathrm{Al}_{2} \mathrm{O}_{8}$ 量でる $\mathrm{CaO}$ が30\%添加されると抵抗は1.5倍に も達する。Fig. 5 はスラグ量一すなわちスラグ高さ

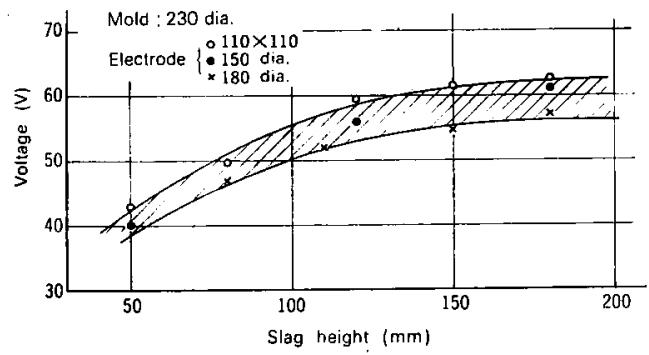

Fig. 5. Relationship between slag amount (height) and melting voltage.

と電压の関係をプロットしたもので，極端に少ないス ラグでは界面フークを発生し易いため採用されない が，ある高さまでは電圧はスラグ量に比例して増大 し，その後は活泀一定の值となる。この原因は清型側 面を電流か流れるためとされており，実操業でも細い 電極を使用すれば高い電圧を維持することができる。

\section{1. 3 溶解電流と電圧の関係}

スラグ浴が抵抗を有して電圧か決まっているため, 当然溶解電流は電流密度, すなわち電極断面積に左右 される。溶解電流と電压の関係は直線になるべきであ るが，実際には前述のようにモールド側面に流れる電 流, スラグ温度, および組成変化に伴 う固有担抗の変 化により直線的には変化しない。その関保を Fig. 6 に示す。この関係から明らかなよ5にVAR と異なっ

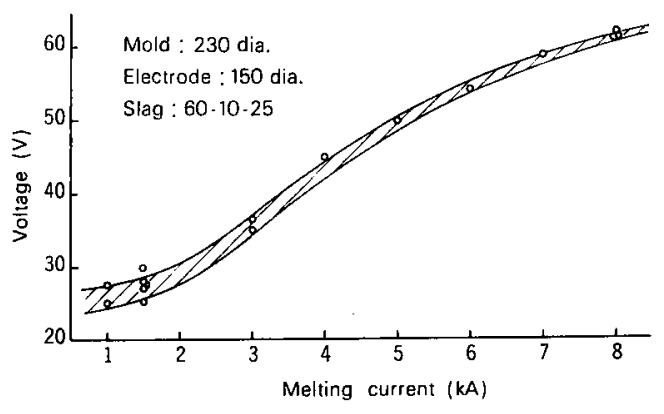

Fig. 6. Relationship between melting electric current and voltage.

て電流の制御たシけで溶解速度を制御することが困難で ある。

\section{1.4 電圧の品翼に及影警}

電圧が品質におよほす影響についての報告は少な い。しかし，電圧が高、アークが発生した場合には鋼 中の酸素が増加するとの報告12) むあり，アーク発生 域（高電圧域）での溶解効率は著しく高いか浃用的で ない。

スラグ量を少なく径 $230 \mathrm{~mm}$ 鋳型で40V前後で溶解し た場合の欠俩の例を Photo. 1 亿示す。この欠楩は溶 解時のメタルプール形状の差によるすのと考えられ る2)。

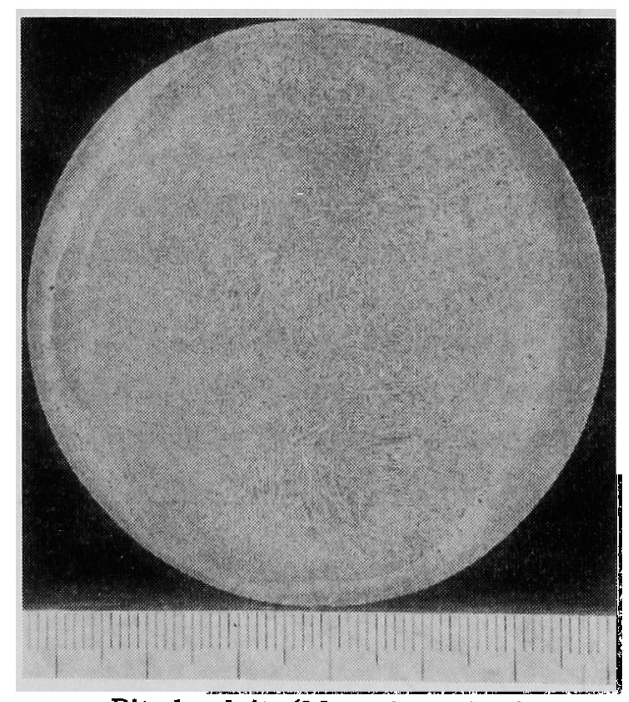

Pit dendrite(Material SCM3)

Photo. 1. Defect example due to low voltage melting.

\section{2 溶解電流の影響}

溶解速度を決定する最大のパラメータとして電流 がある。溶解速度か電流に比例することはよく知られ ており，たとえば溶解速度の決定の式としてS. Joshi 
らの式4) $. . \cdots R \propto R V^{a}: I^{b}: d^{c} / D^{e} \cdot(1 / D)^{f}$ がある。 この式で電圧 (V) の選定範囲が40〜60V 程度， $\mathrm{d} / \mathrm{D}$ は0.5〜0.75の範囲であるのに比し電流(I)は鋳型径の 15倍から35倍程度の範囲に選ぶことがでるため制御 要素としては重要である。溶解量はスラグが一定の場 合, 投入電力量に比例するといわれているか，実際に は後述のよ5に, 初期スラグ温度および装置の力率, 前述の電圧条件などによって左右され直線的には比例 しない。

溶解速度を一定，あるいは任意に制御したいとい5 要求の一つは凝固とのバランスでメタルブール深さ一 すなわち凝固速度を任意に制御したいという理由によ る。

\section{2. 1 溶解電流と溶解速度の関係}

溶解速度は前述のよ5に入力（電压 $\times$ 電流）によっ て決まるが実際にはFig.7のよ5に溶解スタート後

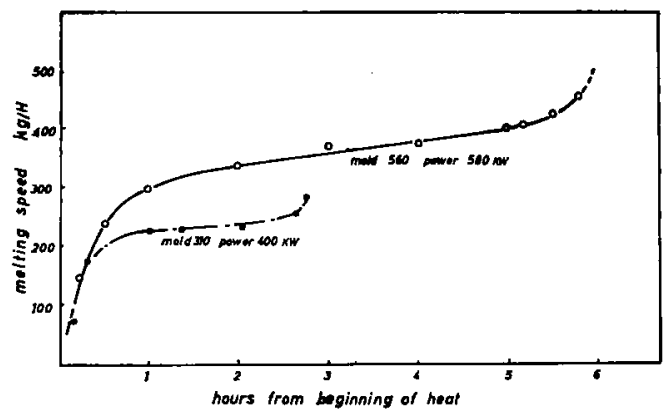

Fig.7. Variation of melting speed during ESR process.

の時間に伴い变化する。この原因はスラグの温度上 昇, 電極の温度上昇, スラグ浴からの輻射, 伝熱, メ タルプールから冷却水への伝熱と熱バランスが多岐に わたり，有効に使用されるエネルギーが20４0\%と少 ないためである。Fig. 8 に電極の温度上昇の一例を 示すが電極の断面積一すなわちd/Dにより温度上昇に

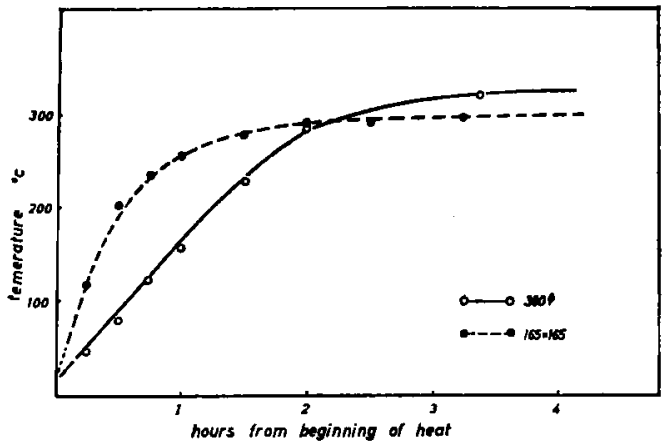

Fig. 8. Variation of electrode temperature during remelting.
差がでるがいずれもある平衡点まで上昇する。したが って，溶解電流による平衡に達した溶解速度を求める には時間の要素を考点る必要がある。

\section{2.2 溶解電流によるメタルプールの変化}

同一スラグを使用し，溶解電流を変えた場合のメタ ルプール深さの変化を調べたのが Fig. 9 である。溶

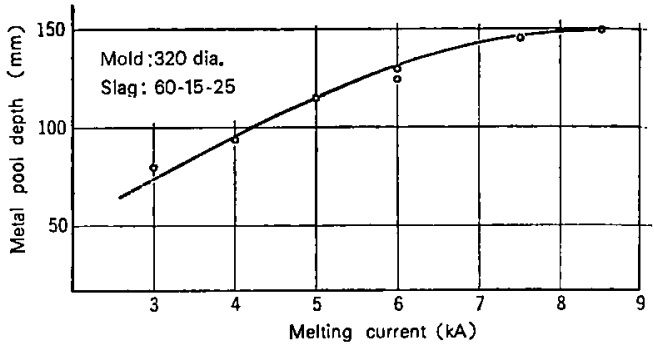

Fig. 9. Relationship between metal pool depth and meltng current.

解電流が増加するとプールが深くなるが，溶解電流に 比例して深くはならない。これはすでに文献にあるよ らに円錐状のプール上に円筒状のプールが存在してい るためと推察される。しかし，ある限界を越壳た溶解 速度になると凝固が遅れメタルプールが深くなること は衆知の事実である。

\section{3 スラグの影零について}

2. 3. 1 スラグの理類について

ESRに使用されるスラグについては多くの報告 7 9'があり，いまさら取り上げるまであないが溶解パ ラメータとしての意義から芳えてみたい。

スラグの基本系としてつぎのようなスラグがある。 $\mathrm{CaF}_{2}$

$$
\begin{aligned}
& 2 \text { 元系…… } \mathrm{CaF}_{2}-\mathrm{CaO} \\
& \mathrm{CaF}_{2}-\mathrm{Al}_{2} \mathrm{O}_{3} \\
& 3 \text { 元采 } \cdots \cdots \mathrm{CaF}_{2}-\mathrm{CaO}-\mathrm{Al}_{2} \mathrm{O}_{8} \\
& \mathrm{CaF}_{2}-\mathrm{Al}_{2} \mathrm{O}_{3}-\mathrm{MgO} \\
& \mathrm{CaF}_{2}-\mathrm{Al}_{2} \mathrm{O}_{8}-\mathrm{SiO}_{2} \\
& \mathrm{CaF}_{2}-\mathrm{CaO}-\mathrm{SiO}_{2} \\
& \mathrm{CaF}_{2}-\mathrm{Al}_{2} \mathrm{O}_{8}-\mathrm{TiO}_{2} \\
& \text { 多元系 } \cdots \cdot \mathrm{CaF}_{2}-\mathrm{CaO}-\mathrm{Al}_{2} \mathrm{O}_{3}-\mathrm{MgO} \\
& \mathrm{CaF}_{2}-\mathrm{CaO}-\mathrm{Al}_{2} \mathrm{O}_{3}-\mathrm{SiO}_{2} \\
& \mathrm{CaF}_{2}-\mathrm{CaO}-\mathrm{Al}_{2} \mathrm{O}_{3}-\mathrm{MgO}-\mathrm{SiO}_{2} \\
& \mathrm{CaF}_{2}-\mathrm{CaO}-\mathrm{Al}_{2} \mathrm{O}_{3}-\mathrm{TiO}_{2}
\end{aligned}
$$

上記のスラグは基本系であり， $\mathrm{CaO}, \mathrm{Al}_{2} \mathrm{O}_{8}$ などの 配合より数多くのスラグに分かれるが，実際に使用さ れるスラグはそれ注ど多くはなく10種類程度である。 その代表的なスラグとおむな特改をTable 1 に示す。 スラグの溶解におよ㴗す影響としては電流，電圧な 


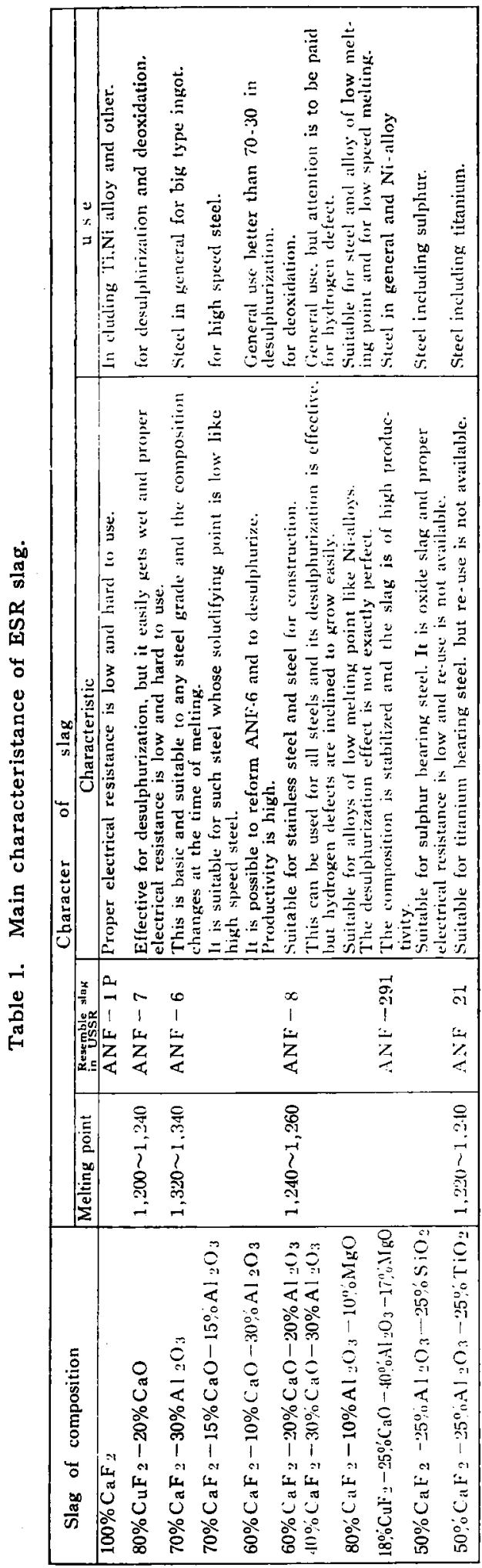

どに関係して溶解速度に与える影響，鋼塊のはだ，精 錬反応などに与える影響を考える必要があり，要求さ れる品質によりスラグの 種類を決めなければならな い。また，使用上の注意としては $\mathrm{CaF}_{2}$ の高いスラグ を使用する時,モールド条件，溶解条件によるが $\mathrm{CaF}_{2}$ が分解して $\mathrm{CaO}$ となりスラグ組成を変化させる。 Fig.10にその一例を示すが，大型鋼塊ではこの組成 の変化は重要な問題である。

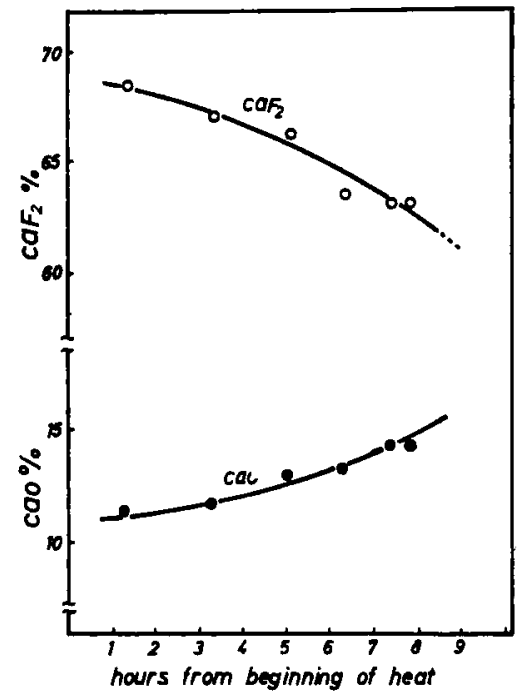

Fig. 10. Variation of $\mathrm{CaF}_{2}$ and $\mathrm{CaO}$ during remelting.

\section{3. 2 スラグの溶解速度に及ぼす影翌}

スラグの種類により同一溶解速度を得るための投入 電力を調べたのが Table 2 である。溶解速度は, 前 述のよ 5 に同一電力でも時間とともに変化するのでで きるだけ平衡に近い所を採用してある。表からわかる よらにスラグの種類によってかなり異なる。

2. 3. 3 スラグ基の影電について

スラグの量を決める因子は鋳型寸法と電極鋳型径比 である。スラグ量については今までに断片的に報告12) されているが， d/Dおよび溶解法によるスラグ量の範 囲をFig.11 に示す。

Fig.11 は溶解のおよその 目安を与えるものであっ てこの範囲をはずれたら品質が悪くなるとい5ことは ない。しかし，考え方として若干多めのスラグ量の方 が安定した溶解が行われる。

なお，スラグ量で注意をする点は溶解中スラグ高さ を一定にすることで，溶解中に鋳型壁との間に生ずる 薄い固相スラグ層による減少を補正することが必要 で，とくに大型鋼塊では留意する必要がある。 
Table 2. Relationship between slag composition and melting electric power.

\begin{tabular}{l|r|r} 
& \multicolumn{2}{|c}{ Melting Power (kW) } \\
\cline { 2 - 3 } Slag composition Melting rate & $150 \mathrm{~kg} / \mathrm{hr}$ & $200 \mathrm{~kg} / \mathrm{hr}$ \\
\hline $70 \% \mathrm{CaF}_{2}-30 \% \mathrm{CaO}$ & 280 & 340 \\
$70 \% \mathrm{CaF}_{2}-30 \% \mathrm{Al}_{2} \mathrm{O}_{3}$ & 220 & 280 \\
$70 \% \mathrm{CaF}_{2}-15 \% \mathrm{CaO}-15 \% \mathrm{Al}_{2} \mathrm{O}_{3}$ & 280 & 330 \\
$60 \% \mathrm{CaF}_{2}-20 \% \mathrm{CaO}-20 \% \mathrm{Al}_{2} \mathrm{O}_{3}$ & 260 & 320 \\
$40 \% \mathrm{CaF}_{2}-30 \% \mathrm{CaO}-30 \% \mathrm{Al}_{2} \mathrm{O}_{3}$ & 230 & 280 \\
$80 \% \mathrm{CaF}_{2}-10 \% \mathrm{Al}_{2} \mathrm{O}_{3}-10 \% \mathrm{MgO}_{3}$ & 320 & 400 \\
\hline
\end{tabular}

Mold $230 \mathrm{inm} \phi \quad$.. Electrode $150 \mathrm{~mm} \phi$

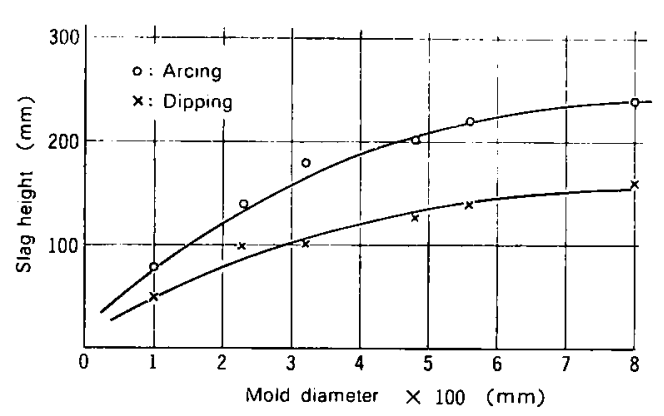

Fig.11. Relationship between mold value and slag amount(slag height).

\section{4 電極鋳型徍比の影幚}

d/Dにより溶解速度に大きな差があることはすでに 報告13 18)されており，その一例を Fig.12に示す か，同一電力を投入した場合には $\mathrm{d} / \mathrm{D} に よ り$ 溶解速 度, および電力消費量に差を生じる。 $\mathrm{d} / \mathrm{D}$ と溶解速度 の変化の程度はスラグの固有抵抗によっても異なり， その関俰を Fig. 13 に示す。 $\mathrm{CaO} / \mathrm{Al}_{2} \mathrm{O}_{3}$ が約 1 のス

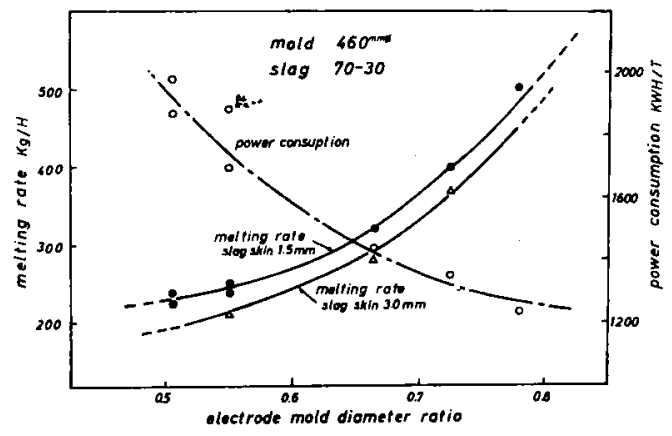

Fig. 12. Relationship between electrode mold diameter ratio and melting rate, power consumption.

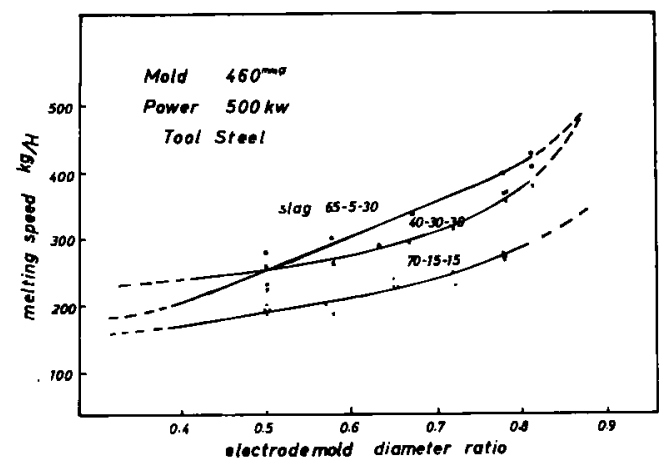

Fig. 13. Relationship between electrode mold diameter ratio and melting speed.

ラグは溶解速度の変化が比較的ゆるやかであるが， CaOの少ないスラグは変化が大きい。この原因の一つ はスラグの組成変化と考えられる。

\section{5 電力消費量について}

電力消費量は投入電力に対する溶解速度で決まるが $\mathrm{t}$ 当り $1,000 \sim 2,400 \mathrm{kWh}$ にも達する。モールド径の 小さい場合には電流密度, すなわち単位面積当りの電 力投入量か高く電力消䖯量も多い。

Fig.14 にスラグの種類，溶解速度との関係を示す か，省䉓力対策としてはd/Dを大きく取り，固有抵抗 の高いスラグを使用することにより $1,000 \mathrm{kWh} / \mathrm{t}$ に 近い值が得られる。しかしスラグ浴を介し，なお温度 が高いため VAR K比較して20\%以上電力消費量が多 wo

\section{3. 溶湯プール深さの実測と溶解パラメータとの 関係}

溶解時のメタルプール樑さの実測方法としてて線を 用いて行 5 方法があるが一般的でなく，普通はプール 


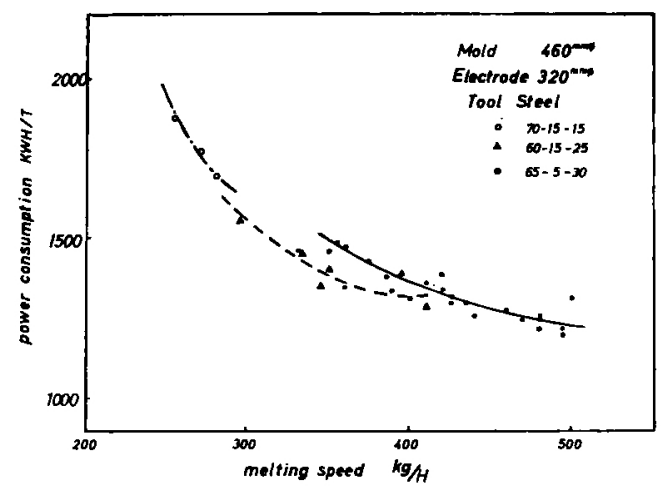

Fig. 14. Relationship between melting speed and power consumption.

形状を凝固後鋼塊を繸断してサルファープリント，マ ク口腐食して測定する方法が取られている。

凝固前線を固定する方法として

1) 同位元素を用いる方法。

2）合金，合金鉄（Fe-W）を添加する方法。

3）硫化物を添加し，サルファープリントにより確 諗する方法。

などがある。手軽にできる方法としては Fe-S を投入 する方法が探用されており，VARの㭙のプール測定 などにはよく使用される。しかし，ESRの場合は投 入するのが強塩基性のスラグの上であり，投入後，プ 一ル全体に拡散混合するのに時間がかかる。

ブール樑さの央測の一例を Photo. 2 に示す。

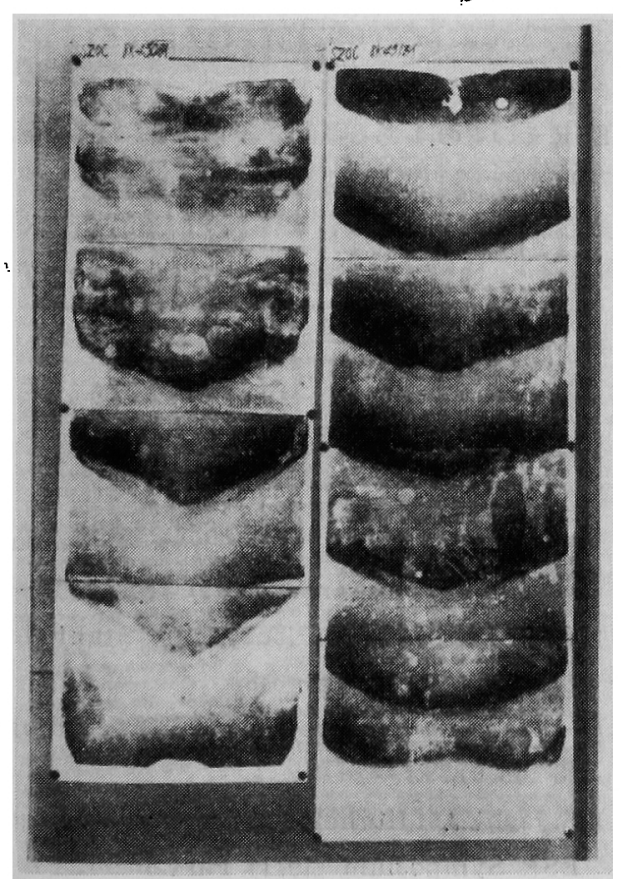

Photo. 2. Sulfur print of ESR ingot(310mm).

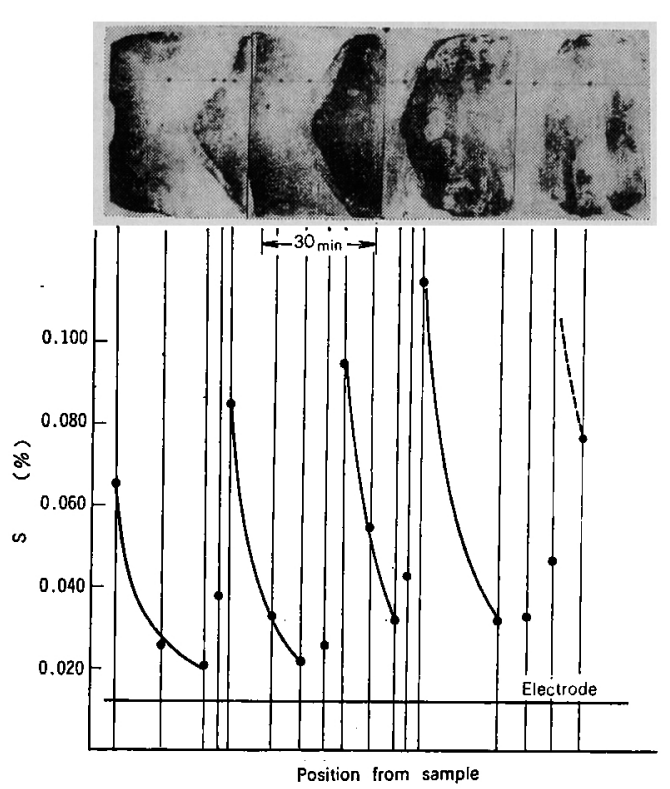

Fig. 15. Dispersion of sulphur and de-sulphurization in metal pool.

Fig. 15 は Fe-S $500 \mathrm{~g}$ （モールド径 $320 \mathrm{~mm}$ ) S 換 算 $182 \mathrm{~g}$ を投入した場合で $\mathrm{S}$ の分析值の例である。

Photo.2 およびFig. 15 でわかるよ5に中心部の半凝 固相で拡散の遅れが認められるが，固相一液相の幅の 少ない周辺部では明確に判別できる。

強程基性スラグを介してのSの添加歩留は12〜20\% であり，スラグ中の Sは最大 $0.5 \%$ をて増加し，スラ

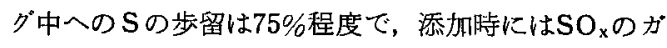
スが放出される。スラグ中の S は $20 \mathrm{~min}$ 後に0.5\%か ら0.08\%をで隇少し，ある程度の間隔をおけばかなり 細かくブールの経時変化の測定が可能である。

\section{1 スラグの種類によるプール深さの変化}

プール形状,メタルプール深さの実測結果をFig. 16 に示すが，同一投入電力を投入してもスラグの種類に

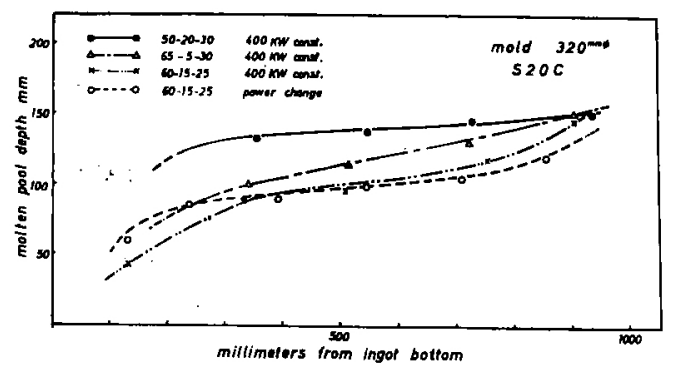

Fig. 16. Variation of molten pool depth during remelting. 
よってかなり異なり，溶解速度が増大する後半はかな りプールが梁くなり末期電力の調整を必要とすること がわかる。なお，図中でもわかるがスラグの固有抵抗 が大きく組成変化の少ないスラグーたと党ば50-20-30 を使用した場合，ブールがかなり深いことがわかる。

\section{2 溶解速度とプール深さの変化}

Fig. 17 に溶解速度の変化とプール深さの変化の関

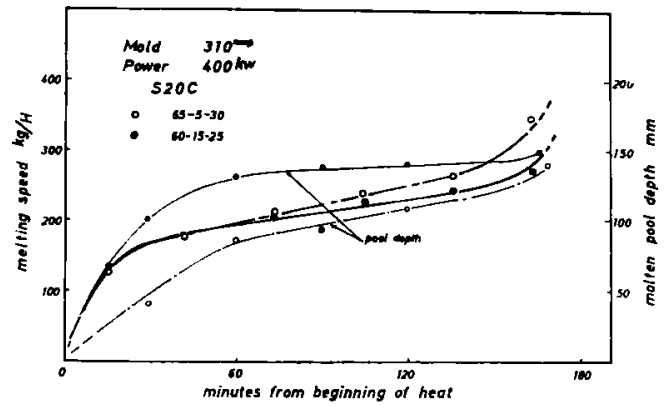

Fig. 17. Variation of melting speed and molten pool depth during remelting.

俰を示すが，溶解速度とプール樑さとは必ずしも比例 しない。この原因は下部泠却の影響があると同時にス ラグの種類，プール浴の温度にかなり差があることに 基因する。

\section{4. 溶解パラメータの相互関係について}

溶解パラメータの相互関係については MullerAueら1により明らかにされている。報告では詳細 が記載ざれていないが，溶解パラメータ単独で条件を 選定することは難しい。

相互関係を整理するとつぎのと扣りである。 溶解速度一投入電力, スラグ組成, 鋼種, $\mathrm{d} / \mathrm{D}, \mathrm{kWh} / \mathrm{t}$

一電流, 電压

入力(電流・電圧)一溶解速度, スラグ組成, 量, $\mathrm{d} / \mathrm{D}$ スラグ組成一電圧, 電流, プール樑さ, 溶解速度

スラグ量一電圧, ブール樑さ， d/D

以上のように溶解パラメータは互いに関連しあって おり，独立に変化し得るものでなく相互の関連におい て溶解条件が決まる。

一方，品質の面から見るとつぎのような要因によっ て決まる。

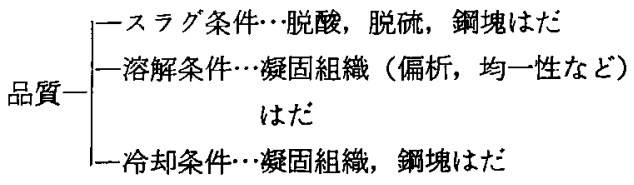

溶解にはこれらの諸条件を踏まえて Fig.18にその

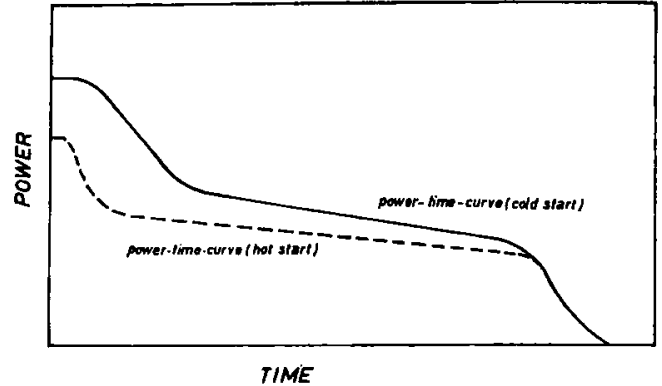

Fig. 18. Schematic drawing of melting pattern.

例を示すよ5な通電パターンを採用してて溶解を制御す る。

\section{5. あとがき}

溶解パラメータの相互関係については公表されたデ ータが少なく，断片的であり再品質との関連づけでは 充分検討されていない。ESR は装置そのものが各社 で異なり，電極の作り方もまちまちであり，また品質 に対するニーズも一様でないため，一つのまとまった 結論を得ることは困難である。

今回記述した溶解パラメータについても内容が断片 的となり，とくに品質との関連については詳述できな かったが，ESR の溶解の参考になれば幸いである。 とくに径が $600 \mathrm{~mm}$ 以上大型鋼塊に対するデータがな く，大型鈵塊に発生する凝固上の問題，スラグ組成の 安定性，ホットトップ法などは今後の研究を待つ必要 がある。

ESRそのものはある条件を与充れば容易に美雁な はだの鋼塊が得られるが，最低の電力消費量，頭部か ら底部までの均一な品質，炭化物の微細化，VAR 上

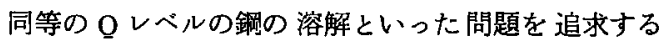
時, 溶解パラメータが重要な意味を持ってくる。した がって未解決な面の理論的解明が必要である。

（文 献）

1) H. J. Muller-Aue : Proceedings of Vacuum Metallurgy conference (1971) N.Y 19 23

2) W. Holzgruber, E. Plöckinger: Stahl u. Eisen 88 (1968) 638 648

3) H. J. Klein : Electric furnace Proceedings 28 (1970), 21

4) S. Jashi, A. Mitchell : Proceedings of 3rd ESR Symposium (1971) Part 1

5) H. Kajioka et al. : Proceedings of 4th ESR 
Symposium (1973), 102 104

6) T. Ohmura et al. : Proceedings of 3rd ESR Symposium (1971) Part 2

7) D. J. Salt : Proceedings of First ESR Symposium (1967) Part 1

8) 山口, 梶岡: 日本金属学会シンポジュウム“溶融 スラグの物性と製鍊”（1972）No.4

9) 江口：金属材料 11 (1971) 11, 12

10) W. E. Duckworth, G. Hoyle : Electroslag refining (1969), 80 Chapman and Hall
11) J. W. Tommaney, A. Kraai : Proceedings of 3rd ESR Symposium (1971) Part 1

12) R. Schlatter : Metals Engineering Quarterly 12 (1972) $1,48 \sim 60$

13）草道, 福原：鉄々鋼 52 (1966) 13，1890

14) K. Yamaguchi et al. : Proceedings of 4 th ESR Symposium (1973), 91 101

15）泉田ら：鉄と鋼 59 (1974) 4, S 119

16) W. Holzgurber et al. : proceedings of 3rd ESR Symposium (1971) Part 3

\title{
ShKh 15 ボールベアリング鋼の EBR 中におけるアルミナ介在物の挙動
}

\author{
Steel USSR, $3(1973) 9, \quad 742 \sim 743$
}

E B炬により ShKh 15 ボールベフリング鋼を再溶 解し，溶銅を直接モールド中またはタンディッシュを 通してモールド中に鋳込んた場合のアルミナ介在物の 挙動について調查した。

再溶解プロセス中, 電極の先端およびタンディッシ ュ端部の鋼滴から採取した試料括よび電極, 鋼塊から 採取した試料について影微鏡（625 倍）による介在物 の測定を行なった。

溶解酸素の 60 ～80\%は EBRによりCOとして除去 され，残部の酸素は新しい介在物として凝固中に遊離
ナる。大型介在物は再溶解中にメタル/ガス界面に移 行することによりある程度除去される。移行速度は介 在物の直径の 2 乗に活潘比例する。10 $\mathrm{\mu m}$ より大型の フルミナ介在物は完全に除去され， $5 \sim 8 \mu \mathrm{m}$ 径のも のは約50\%が除去される。

EBR でタンディッシュを使用したすのは，使用し ないで直接鋳込んだものに比較して，メタルの溶融状 態の時間の増加のため, アルミナ介在物は半量近くま で隇少する。（図 2, 表 1)

\section{ステンレス鋼及び合成 $\mathrm{CaO}-\mathrm{Al}_{2} \mathrm{O}_{3}$ スラグの表面性質}

\author{
Steel USSR, 3 (1973) $10,828 \sim 830$
}

合成スラグ組成の正しい選択並びに精鍊中における 種々の要因（メタルおよびスラグの温度と化学組成な ど）の影響測定のため，Crおよび Cr-Ni ステンレス 鋼並びに合成 $\mathrm{CaO}-\mathrm{Al}_{2} \mathrm{O}_{3}$ スラグの表面性質につい て調查した。

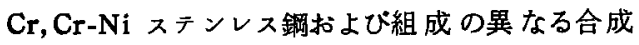
$\mathrm{CaO}-\mathrm{Al}_{2} \mathrm{O}_{8}$ スラグの $1600,1650,1700^{\circ} \mathrm{C}$ における密 度，表面張力の測定を行なった。

メタルおよびスラグの密度と表面張力, メタル/ス
フグ界面における粘着性は温度低下と共に增加する。 通常溶解したメタルの表面張力は，合成スラグで処理 したメタルより幾分抵く，また $\mathrm{Na} 2 \mathrm{O}$ おび $\mathrm{NaCl}$ を添加した $\mathrm{CaO}-\mathrm{Al}_{2} \mathrm{O}_{3}$ スラグの表面張力は通常の $\mathrm{CaO}-\mathrm{Al}_{2} \mathrm{O}_{8}$ スラグよりす低い。

$\mathrm{Cr}, \mathrm{Cr}-\mathrm{Ni}$ ステンレス鋼の処理に批ては, 一般の 組成を有する合成スラグ—-50\% $\mathrm{CaO}, 42.5 \% \mathrm{Al}_{2} \mathrm{O}_{3}$, $2.5 \% \mathrm{SiO}_{2}, 2 \% \mathrm{MgO}, 0.5 \% \mathrm{Fe}$ 一を推奖する。 （図3,表 2) 